
\title{
JURNAL AKUNTANS!

\section{PERAN SATUAN PENGAWASAN INTERN DAN PENERAPAN \\ PENGENDALIAN INTERNAL TERHADAP PENCAPAIAN GOOD UNIVERSITY GOVERNANCE PADA PERGURUAN TINGGI DI KOTA BENGKULU}

\author{
Dri Asmawanti S 1), Siti Aisyah ${ }^{2)}$ \\ Fakultas Ekonomi dan Bisnis Universitas Bengkulu \\ dri_asmawanti@yahoo.com ${ }^{1}$ ), sitiaisyah@gmail.com ${ }^{2}$ )
}

\begin{abstract}
The research was aimed to examine and obtain empirical evidence of the influence from role of internal control unit and controling system internal to achievement of Good University Governance in College with state in Bengkulu City. The data was collect from questioner that direclty spread to the all responden. The result of this study explained that role of internal control units and controlling system internal has positively significance influence to achievement of Good University Governance.
\end{abstract}

Keywords : Internal control unit, controlling system internal

\section{PENDAHULUAN}

Pendidikan tinggi dituntut untuk terus mengembangkan kinerjanya dengan beragam perannya yang cukup besar. Berbagai permasalahan bangsa yang sedang dihadapi oleh Negara Indonesia membutuhkan berbagai perbaikan dalam bidang pendidikan tentunya, Pendidikan Tinggi dalam prakteknya dapat menjadi salah satu komunitas intelektual yang mampu memberikan pemikiran dan inovasi dalam menghadapi masalah bangsa (Wijatno, 2009). Good University Governance $(G U G$ ) salah satu bentuk penerapan prinsip-prinsip dasar Good Governance dalam sistem dan proses pengelolaan institusi perguruan tinggi, dengan melewati proses penyesuaian yang dijunjung tingi oleh penyelenggaran perguruan tinggi secara khusus dan pendidikan secara umum (Wijatno, 2009).

Terdapat lima prinsip Good University Governance (GUG) yang dapat diterapkan oleh perguruan tinggi, yaitu transparansi, akuntabilitas, responsibilitas, independensi dan keadilan. Dengan menerapkan prinsip tersebut, diharapkan perguruan tinggi dapat meningkatkan kualitas perguruan tingginya dan mampu mencegah terjadinya fraud (Wijatno, 2009). Dengan demikian, perguruan Tinggi perlu mendapat dukungan dari beberapa pihak dalam tata kelola perguruan tinggi tersebut. Dilihat dari beberapa kasus mengenai laporan keuangan Perguruan Tinggi yang diaudit oleh Satuan Pengawasan Intern, masih terdapat ketidaksesuaian dengan standard peraturan yang berlaku serta banyak penyimpanganpenyimpangan lain seperti halnya penggelapan dana kas Universitas Bengkulu yang melibatkan langsung bendahara pengeluaran perguruan tinggi tersebut. Berikut ini, kutipan dari media masa Antara Bengkulu, yang menjelaskan salah satu kasus penggelapan yang terjadi di Universitas Bengkulu :

"Disentil oleh tersangka Bendahara Pengeluaran Firman Azhari, terkait adanya andil pejabat Universitas Bengkulu dalam kasus dugaan penggelapan uang kas sebesar Rp 5,2 Miliar. Melalui pengacaranya siap mengungkapkan otak utama dalam kasus pembobolan kas 
Unib ini. Sebab Firman merasa tidak sendirian membobol uang hasil pembayaran SPP, Pratikum dan PKL mahasiswa Unib tersebut. Menurutnya ada juga pejabat Unib yang terlibat dalam pembobolan tersebut". Akibat perbuatan terdakwa Saipuddin, S.H. alias Udin bin (Alm) Dulsahab bersama dengan saksi Muhamad Firman Ashari, Amd alias Boy bin Bustari Ishak, telah mengakibatkan kerugian keuangan Negara dalam hal ini Universitas Bengkulu sebesar Rp1.509.161.792,00 (satu miliar lima ratus sembilan juta seratus enam puluh satu ribu tujuh ratus sembilan puluh dua rupiah) atau setidaknya sekitar jumlah tersebut". (Laporan Hasil Audit Badan Pengawas Keuangan dan Pembangunan Perwakilan Provinsi Bengkulu Nomor 0393/PW06/5/2013 tanggal 08 Juli 2013).

Berdasarkan kasus diatas, dapat dilihat bahwa pengelolaan perguruan tinggi di Bengkulu masih belum maksimal, khususnya di Universitas Bengkulu. Hal ini berkaitan dengan Satuan Pengawasan Intern (SPI) sebagai salah satu faktor yang berkontribusi dalam mewujudkan tata kelola perguruan tinggi atau Good University Governance (GUG). Satuan Pengawasan Intern (SPI) merupakan salah satu satuan kerja yang menunjang terwujudnya Good University Governance $(G U G)$ yang pada saat ini telah berkembang menjadi komponen utama dalam meningkatkan tata kelola perguruan tinggi secara efektif dan efisien. Perguruan tinggi mampu memberikan kontribusi positif melalui pengimplementasian lima prinsip Good University Governance $(G U G)$ yang dibantu oleh satuan kerja, salah satunya adalah Satuan Pengawasan Intern (SPI) atau audit internal yang dimiliki oleh perguruan tinggi.

Sistem pengendalian internal yeng efektif dapat menjamin operasi perusahaan yang efektif dan efisien serta dipatuhinya aturan-aturan internal perusahaan dan aturan dari luar yang terkait dengan perusahaan sehingga dapat terciptanya akuntabilitas (Gusnardi, 2008). Peran Satuan Pengawasan Intern (SPI) dan pengendalian internal yang baik diharapkan membantu pimpinan unit kerja dalam mencapai tujuan yaitu terwujudnya Good University Governance $(G U G)$. Beberapa penelitian mengenai peran satuan pengawasan intern dan penerapan pengendalian internal dalam pencapaian Good University Governance telah dilakukan dibeberapa perguruan tinggi. Salah satunya adalah penelitian Puspitarini, dkk (2013), hasil penelitiannya membuktikan bahwa peran satuan pengawasan intern berpengaruh positif dalam pencapaian $G U G$. Semakin baik peran satuan pengawasan intern dalam perguruan tinggi maka akan semakin cepat $G U G$ dapat tercapai. Sama halnya dengan penelitian yang dilakukan oleh Untari (2015) mengenai pengaruh peran Satuan Pengawasan Intern dan penerapan Internal Control terhadap pencapaian $G U G$ menunjukkan bahwa peran Satuan Pengawasan Internal dan penerapan Internal Control berpengaruh positif terhadap pencapaian Good University Governance.

Responden yang digunakan dalam penelitian ini adalah perguruan tinggi yang memiliki satuan pengawasan intern yang berada diwilayah Kota Bengkulu dan indikator ukuran yang digunakan untuk peran Satuan Pengawasan Intern adalah peran auditor internal menurut Sawyer, dkk (2010). Tujuan dari penelitian ini adalah untuk menganalisis hubungan antara Peran Satuan Pengawasan Intern dan Penerapan pengendalian internal terhadap pencapaian Good University Governance.

\section{KERANGKA TEORI DAN HIPOTESIS}

\section{Stewardship Theory}

Teori stewardship adalah teori yang mempunyai dasar psikologi dan sosiologi yang telah dirancang dimana para eksekutif sebagai stewards, termotivasi untuk bertindak sesuai keinginan principal, dimana para manajer termotivasi oleh sasaran hasil utama mereka untuk 
kepentingan organisasi dan berusaha mencapai sasaran organisasinya. Teori ini menggambarkan situasi dimana para eksekutif dalam perusahaan sebagai pelayan dapat termotivasi untuk bertindak dengan cara terbaiknya pada principalnya. Berdasarkan teori stewardship, principal mengharapkan tanggung jawab bersama sesuai dengan kontribusi steward. Proposisi orang yang termotivasi oleh perintah yang lebih tinggi dan faktor instrinsik lebih cocok menjadi stewards dalam hubungan principal steward dibandingkan orang yang tidak termotivasi oleh perintah dan faktor ekstrinsik (Donaldson dan Davis, 1989, 1991) dalam Raharjo (2007).

\section{Satuan pengawasan Intern (SPI)}

Peraturan Menteri Pendidikan Nasional Nomor 47 Tahun 2011 Pasal 1 Ayat 2 menjelaskan bahwa SPI adalah satuan pengawasan yang dibentuk untuk membantu terselenggaranya pengawasan terhadap pelaksanaan tugas unit kerja di lingkungan kementerian pendidikan nasional. Menurut Zarkasyi (2008), Satuan Pengawasan Intern di Perguruan Tinggi bertanggungjawab kepada Rektor dan seluruh unit kerja yang membawahi tugas pengawasan internal. Satuan pengawasan intern berfungsi dan bertugas membantu Rektor dalam memastikan pencapaian tujuan dan misi universitas dengan melakukan evaluasi terhadap pelaksanaan program universitas, memperbaiki efektifitas proses pengendalian risiko, melakukan evaluasi kepatuhan universitas terhadap peraturan universitas dan perundang-undangan, memfasilitasi kelancaran pelaksanaan audit oleh auditor eksternal.

Menurut Tugiman (1997) audit internal harus mandiri dan terpisah dari kegiatan yang diperiksanya (independensi). Kemampuan lainnya adalah professional yaitu, dalam melaksanakan kegiatannya satuan pengawasan intern harus mencerminkan keahlian dan profesionalnya untuk mendapatkan hasil yang maksimal. Lingkup pekerjaan auditor internal harus meliputi pengujian dan evaluasi terhadap kecukupan serta efektivitas sistem pengendalian internal yang dimiliki organisasi dan kualitas pelaksanaan tanggungjawab yang diberikan manajemen bagian audit internal.

Auditor dapat memberikan manfaat berupa nasehat dalam pengelolaan sumber daya organisasi sehingga dapat membantu tugas para manajer operasional. Audit yang dilakukan adalah operational audit atau performance audit, yaitu meyakinkan bahwa organisasi telah memanfaatkan sumber daya organisasi secara ekonomis, efisien dan efektif sehingga dapat dinilai apakah manajemn telah menjalankan aktivitas organisasi yang mengarah pada tujuannya. Peran auditor sebagai management's representative berkaitan dengan quality assurance, sehingga auditor internal diharapkan dapat membimbing manajemen dalam mengenali risiko-risiko yang mengancam pencapaian tujuan organisasi. Quality assurance bertujuan untuk meyakinkan bahwa proses bisnis yang dijalankan telah menghasilkan produk atau jasa yang dapat memenuhi kebutuhan.

\section{Pengendalian Internal}

Pengendalian internal menurut (COSO, 2013) "Internal control is a process, effected by an entity's board of directors, management, and other personnel, designed to provide reasonable assurance regarding the achievement of objectives relating to operations, reporting, and compliance”. Di Indonesia terdapat Peraturan Pemerintah RI No.60/2008 tentang Sistem Pengendalian Intern Pemerintah. Auditor diharuskan untuk memahami desain dan implementasi pengendalian internal yang diterapkan oleh perusahaan yang diaudit. Kerangka pengendalian internal COSO (2012) menetapkan lima komponen pengendalian internal. Suasana atau Lingkungan Pengendalian (Control Environment) berfungsi sebagai payung bagi keempat-komponen lainnya. Untuk memahami dan menilai lingkungan 
pengendalian, auditor harus mempertimbangkan sub komponen pengendalian yang paling penting, yaitu integritas dan nilai-nilai etis, komitmen kepada kompetensi, partisipasi dewan komisaris atau komite audit, filosofi dan gaya operasi manajemen, struktur organisasi, serta kebijakan dan praktik sumber daya manusia.

Penilaian risiko (risk assessment) atas laporan keuangan adalah tindakan yang dilakukan manajemen untuk mengidentifikasi dan menganalisis risiko-risiko yang relevan dengan penyusunan laporan keuangan yang sesuai dengan GAAP. Aktivitas pengandalian umum dibagi menjadi lima jenis, yaitu pemisahan tugas yang memadai, otorisasi yang sesuai atas transaksi dan aktivitas, dokumen dan catatan yang memadai, pengendalian fisik atas aktiva dan catatan, pemeriksaan kinerja secara independen. Tujuan sistem informasi dan komunikasi akuntansi dari entitas adalah untuk mencatat, memproses dan melaporkan transaksi yang dilakukan entitas itu serta mempertahankan akuntabilitas aktivitas terkait. Untuk memahami perancangan sistem informasi akuntansi, auditor akan menentukan kelas transaksi utama entitas, bagaimana transaksi dicatat, catatan akuntansi apa saja yang ada serta sifatnya, bagaimana sistem itu menangkap peristiwa lain yang penting bagi laporan keuangan, seperti penurunan nilai aktiva, dan sifat serta rincian proses pelaporan keuangan yang diikuti, termasuk prosedur pencatatan transaksi dan penyesuaian dalam buku besar umum. Pemantauan (Monitoring) yaitu, aktivitas pemantauan berhubungan dengan penilaian mutu pengendalian internal secara berkelanjutan atau periodik oleh manajemen untuk menentukan bahwa pengendalian itu telah beroperasi seperti yang diharapkan dan telah dimodifikasi sesuai dengan perubahan kondisi.

Kerangka pengendalian internal COSO (2012) menyatakan 17 prinsip yang merepresentasikan konsep - konsep fundamental yang terkait dengan tiap - tiap komponen pengendalian internal. Prinsip - prinsip pengendalian internal dirumuskan langsung dari komponen pengendalian internal, sehingga entitas akan mencapai pengendalian internal secara efektif dengan menerapkan semua prinsip.

\section{Good University Governance (GUG)}

Menurut Wijatno (2009) secara sederhana Good University Governance dipandang sebagai penerapan prinsip-prinsip dasar konsep "good governance" dalam sistem dan proses governance pada institusi perguruan tinggi melalui berbagai penyesuaian yang dilakukan berdasarkan nilai-nilai yang harus dijunjung tinggi dalam penyelenggaraan perguruan tinggi secara khusus dan pendidikan secara umum, seperti transparansi, akuntabilitas, responsibiliti, independensi dan keadilan yang perlu diterapkan oleh setiap perguruan tinggi untuk mewujudkan perguruan tinggi yang berkualitas.

Menurut Wijatno (2009) pencapaian Good University Governance dapat diukur melalui prinsip-prinsip dasar Good Governance, 5 prinsip. Transparansi (Transparancy) yaitu, perguruan tinggi harus mampu menerapkan prinsip keterbukaan dibidang keuangan, sistem dan prosedur penerimaan mahasiswa baru, sistem dan prosedur akuntansi, pelaporan keuangan, dll. Informasi-informasi penting dalam perguruan tinggi harus diungkapkan kepada semua pemangku kepentingan secara memadai, akurat, dan tepat waktu. Akuntabilitas (Accountability) yaitu, Perguruan tinggi diperlukan kejelasan fungsi, pelaksanaan dan pertanggungjawaban semua orang dalam organisasi, sehingga pengelolaan lembaga terlaksana secara efektif. Perguruan tinggi harus mempunyai uraian tugas dan tanggungjawab yang jelas (secara tertulis). Responsibiliti (Responsibility) yaitu, melalui status perguruan tinggi akan adanya penjabaran kedudukan, fungsi, tugas, tanggungjawab, dan kewenangan setiap unsur organisasi. Setiap individu yang terlibat dalam pengelolaan perguruan tinggi harus bertanggung jawab atas pekerjaan yang mereka lakukan sesuai dengan yang telah ditetapkan.Sesuai dengan adanya job description personel dan standard operating procedure 
(SOP) yang jelas. Independensi (Independency) yaitu, Pihak yayasan dan pengelola perguruan tinggi dalam melaksanakan peran dan tanggungjawabnya harus bebas dari segala benturan kepentingan yang berpotensi untuk muncul. Hal ini diperlukan untuk memastikan bahwa pengambilan keputusan dilakukan secara independen, bebas dari segala bentuk tekanan dari pihak lain, sehingga dapat dipastikan bahwa keputusan itu dapat dibuat demi kepentingan perguruan tinggi. Keadilan (Fairness) yaitu, Perlakuan yang adil dan berimbang kepada para pemangku kepentingan yang terkait. Dalam hal ini, para pemangku kepentingan terdiri atas mahasiswa, masyarakat, para dosen, dan karyawan non akademis, serta pengurus yayasan.

\section{Hipotesis Penelitian \\ Peran Satuan Pengawasan Internal Terhadap Pencapaian Good University Governance}

Good University Governance merupakan langkah yang dapat menunjang pencapaian kualitas suatu perguruan tinggi. Menurut wijatno (2009), beberapa indikator yaitu transparansi, akuntabilitas, responsibilitas, independensi, dan keadilan. Pada prakteknya, keseluruhannya prinsip tersebut harus ditetapkan untuk mewujudkan suatu tata kelola perguruan tinggi yang baik. Dalam upaya pencapaian Good University Governance, perguruan tinggi memerlukan peran Satuan Pengawasan Intern (sektor pemerintah) yang bertugas meneliti dan mengevaluasi suatu sistem akuntansi serta menilai kebijkan manajemen yang dilaksanakan. Satuan Pengawasan Intern atau auditor internal merupakan salah satu profesi yang menunjang tercapainya Good University Governance yang dapat dilihat pada saat ini telah berkembang menjadi komponen utama dalam meningkatkan perguruan tinggi secara efektif dan efisien yang berdasarkan atas prinsip Good Governance.

Peran SPI dalam pencapaian Good University Governance diukur melalui tiga indikators yang diambil dari peran auditor internal. Ketiga indikator tersebut adalah peran auditor internal sebagai audit snoop, peran auditor internal sebagai consultant, peran auditor internal sebagai management's representative. Berdasarkan peneliti yang dilakukan oleh Untari (2015) bahwa peran Satuan Pengawasan Intern berpengaruh positif dalam pencapaian Good University Governance. Artinya, semakin baik peran SPI maka semakin baik pula pencapaian Good University Governance. Hal ini juga sesuai dengan penelitian yang dilakukan oleh puspitarini, dkk (2013) bahwa terdapat pengaruh yang signifikan antara SPI dalam pencapaian Good University Governance. Jadi dapat dikatakan bahwa peningkatan peran auditor internal akan mempengaruhi tata kelola suatu institusi pendidikan. Dengan digunakannya peran auditor internal dalam mengukur peran SPI, diharapkan tata kelola perguruan tinggi yang baik atau $G U G$ dapat dicapai. Sehingga perguruan tinggi akan lebih transparan, akuntabel, bertanggungjawab, independen, dan adil. Berdasarkan uraian diatas dapat disimpulkan bahwa semakin baik peran satuan pengawasan intern dalam melaksanakan tugas dan fungsinya maka Good University Governance akan semakin capat terwujud.

$\mathrm{H}_{1}$ : Peran satuan pengawasan intern berhubungan positif dalam pencapaian Good University Governance.

\section{Penerapan Pengendalian Intenal Terhadap Pencapaian Good University Governance}

Pengendalian internal adalah suatu proses yang dipengaruhi oleh direksi organisasi, manajemen, dan personel lainnya, yang didesain untuk memberikan keyakinan memadai akan tercapinya tujuan dalam kategori berikut, efektivitas dan efisiensi, keandalan pelaporan keuangan, ketaatan pada hukum dan peraturan yang berlaku. Ketiga tujuan pengendalian internal yaitu efektivitas dan efisiensi, keandalan pelaporan keuangan, ketaatan pada hukum dan peraturan yang berlaku adalah cerminan dari organisasi yang memiliki tata kelola yang 
baik, dalam hal ini adalah perguruan tinggi. Pelaksanaan pengendalian internal salah satu faktor yang sangat penting dalam menentukan seberapa baik aktivitas telah dilakukan untuk mencapai tujuan strategis yang ingin dicapai. Pengendalian internal yang baik menunjang GUG yang diukur dengan 5 komponen Internal Control yaitu lingkungan pengendalian, penetapan resiko, aktivitas pengendalian, informasi dan komunikasi, serta pemantauan. Untari (2015) yang mengatakan dari penerapan komponen-komponen dari pengendalian internal yang baik diharapkan tata kelola perguruan tinggi yang baik akan tercapai dengan lebih baik dan lebih efektif. Sehingga tercermin kegiatan yang efektif dan efisien, laporan keuangan yang andal, serta patuh terhadap hukum yang berlaku. Dari penjelasan dapat disimpulkan bahwa Internal Control mendukung tercapainya GUG.

$\mathrm{H}_{2}$ : Pengendalian internal berhubungan positif terhadap pencapaian good university governance.

\section{METODE PENELITIAN}

\section{Jenis Penelitian}

Jenis penelitian ini adalah penelitian kuantitatif. Penelitian kuantiatif adalah penelitian yang banyak dituntut menggunakan angka, mulai dari pengumpulan data, penafsiran terhadap data tersebut, serta penampilan hasilnya, demikian juga pemahaman akan kesimpulan penelitian, akan lebih baik apabila disertai dengan tabel, grafik, bagan, gambar atau tampilan lain (Ghozali, 2011).

\section{Definisi Operasional \\ Peran Satuan Pengawasan Intern (SPI)}

Dimensi dalam variabel pemahaman peran Satuan Pengawasan Intern (SPI) diukur dengan beberapa indikator yang diambil berdasarkan Sawyer, dkk (2010) peran auditor internal meliputi peran auditor internal sebagai audit snoop, peran auditor internal sebagai consultant, peran auditor internal sebagai management's representative. Semua item pertanyaan diukur dengan menggunakan skala interval (Likert), 1 sampai 5.Jawaban yang didapat akan di buat skor yaitu : nilai (1) sangat tidak setuju, (2) Tidak Setuju, (3) Netral, (4) Satuju dan (5) Sangat Setuju.

\section{Penerapan Pengendalian Internal}

Pengendalian internal yang baik menunjang tercapainya $G U G$ yang diukur dengan 5 komponen pengendalian internal yaitu lingkungan pengendalian, penetapan resiko, aktivitas pengendalian, informasi dan komunikasi, serta pemantauan (COSO, 2012). Semua item pertanyaan diukur dengan menggunakan skala interval (Likert), 1 sampai 5.Jawaban yang didapat akan di buat skor yaitu: nilai (1) sangat tidak setuju, (2) Tidak Setuju, (3) Netral, (4) Satuju dan (5) Sangat Setuju.

\section{Pencapaian Good University Governance (GUG)}

Good University Governance merupakan bagian dari Good Governance yang penyelanggaraannya didunia pendidikan yaitu perguruan tingi. Dimensi dalam variabel ini diukur dengan GUG merupakan suatu konsep yang menerapkan prinsip-prinsip dasar Good Governance seperti transparansi, akuntabilitas, respondibiliti, independensi, dan keadilan yang perlu diterapkan oleh setiap perguruan tinggi di Kota Bengkulu untuk mewujudkan perguruan tinggi yang berkualitas. Semua item pertanyaan diukur dengan menggunakan skala 
interval (Likert), 1 sampai 5. Jawaban yang didapat akan di buat skor yaitu: nilai (1) sangat tidak setuju, (2) Tidak Setuju, (3) Netral, (4) Satuju dan (5) Sangat Setuju.

\section{Metode Pengambilan Sampel}

Populasi merupakan keseluruhan wilayah, individu, objek, gejala, atau peristiwa dimana generalisasi suatu kesimpulan akan dikenakan. Sedangkan menurut Ghozali (2011) populasi adalah keseluruhan objek penelitian. Penelitian ini di lakukan pada seluruh perguruan tinggi Negeri di Kota Bengkulu. Populasi dalam penelitian ini adalah Rektor beserta jajarannya dan seluruh Satuan Pengawasan Intern yang bekerja di lingkungan perguruan tinggi Negeri di Kota Bengkulu.

\begin{tabular}{c} 
Tabel 1 \\
Daftar Populasi \\
\hline Perguruan Tinggi Negeri di Kota Bengkulu \\
\hline Universitas Bengkulu \\
\hline Institut Agama Islam Negeri \\
\hline Politeknik Kesehatan Kementerian Kesehatan
\end{tabular}

Teknik penentuan sampel yang digunakan adalah convenience sampling yaitu teknik pengambilan sampel dengan menyebar sejumlah kuesioner dan menggunakan kuesioner yang kembali dan dapat diolah. Pemilihan teknik pengambilan sampel ini dilandasi karena keterbatasan biaya dan waktu, serta kesediaan Rektor beserta jajarannya dan seluruh Satuan Pengawasan Intern/audit internal/audit internal yang masih tergabung dalam LPM atau LPPM sebagai responden. Kriteria yang dijadikan dasar pemilihan anggota sampel pada penelitian ini adalah Rektor beserta jajarannya yang mengetahui secara pasti tugas dan fungsi serta keberadaan audit internal di lingkungan perguruan tinggi dan seluruh Satuan Pengawasan Intern/audit internal/audit internal yang masih tergabung dalam lembaga LPM atau LPPM yang bertanggung jawab langsung kepada Rektor yang bekerja pada perguruan tinggi negeri di Kota Bengkulu.

Penelitian ini dibagi dalam dua responden, responden yang pertama yaitu, Rektor beserta jajarannya yang mengetahuai secara pasti tugas dan fungsi serta keberadaan audit internal di lingkungan perguruan tinggi yang akan mengisi kuesioner mengenai Peran Satuan Pengawasan Intern. Sedangkan untuk responden yang ke dua yaitu, seluruh Satuan Pengawasan Intern/audit internal/audit internal yang masih tergabung dalam lembaga LPM atau LPPM yang bertanggung jawab langsung kepada Rektor yang akan mengisi kuesioner mengenai Penerapan Pengendalian Internal dan Pencapaian Good University Governance.

\section{Metode Pengumpulan Data}

Metode pengumpulan data yang digunakan dalam penelitian ini adalah metode angket (kuesioner) yang dikirim secara langsung kepada responden. Data diperoleh dengan menggunakan kuesioner yang dibagikan secara langsung kepada Rektor beserta jajarannya dan para auditor yang bekerja di unit Satuan Pengawasan Intern di perguruan tinggi. Kuesioner tersebut ditinggal dan diambil kembali sekitar 1 minggu setelah kuesioner diserahkan. Pernyataan pada kuesioner penelitian ini menggunakan kuesiner dari Sawyer, dkk (2010), COSO (2012) dan Wijatno (2009). Peneliti menggunakan skala likert. Skala pengukuran ini digunakan untuk mengklasifikasi variabel yang akan diukur supaya tidak terjadi kesalahan dalam menentukan analisis data dan langkah penelitian selanjutnya. 


\section{Metode Analisis}

Statistik Deskriptif

Statistik deskriptif digunakan untuk menganalisis dan menyajikan sebagian besar data. Statistik deskriptif menampilkan rata-rata (mean), ukuran penyebaran (standar deviasi) dan bentuk konstribusi (nilai minimum dan maksimum) data (Cooper dan Schindler, 2012).

\section{Uji Kualitas Data}

Menurut Ghozali (2011), kualitas data yang dihasilkan dari penggunaan instrument penelitian dapat dievaluasi melalui uji reliabilitas dan uji validitas. Pengujian tersebut masing-masing untuk mengetahui konsistensi dan akurasi data yang dikumpulkan dari penggunan instrumen.

\section{Uji Validitas}

Uji validitas dimaksudkan untuk mengukur sah atau valid tidaknya suatu kuesioner. Suatu kuesioner dikatakan valid jika pertanyaan pada kuesioner mampu untuk mangungkapkan sesuatu yang akan diukur oleh kuesioner tersebut. Pengujian validitas ini menggunakan nilai signifikan dibawah 0,05 (Ghozali, 2011). Jadi dapat disimpulkan bahwa masing-masing indikator pernyataan pada kuesioner valid ketika nilai signifikannya dibawah 0,05 .

\section{Uji Reliabilitas}

Reliabilitas adalah alat untuk mengukur suatu kuesioner yang merupakan indikator dari variabel. Suatu kuesioner dikatakan reliable atau handal jika jawaban seseorang terhadap pernyataan adalah konsisten atau stabil dari waktu ke waktu (Ghozali, 2011). Kriteria pengujian dilakukan dengan menggunakan pengujian Croncbach Alpha (a). Suatu variabel dikatakan reliable jika memberikan nilai Cronbach Alpha > 0,50 (Ghozali,2011).

\section{Uji Asumsi Klasik}

Pengujian hipotesis dalam penelitian ini menggunakan alat analisis berganda (Multiple Regression). Untuk itu diperlukan Uji asumsi klasik yang digunakan dalam penelitian ini adalah uni normalitas, uji heteroskedestisitas dan uji multikolonieritas.

\section{Uji Koefisien Determinasi $\left(R^{2}\right)$}

Uji koefisien determinasi (Adj $\mathrm{R}^{2}$ ) adalah bertujuan mengukur seberapa jauh kemampuan variabel independen (Peran Satuan Pengawasan Intern dan Penerapan Pengendalian Internal) dalam menjelaskan variasi variabel dependen (Good university Governance). Bila koefisien determinasi adalah antara nol dan satu. Nilai yang mendekati satu berarti variabel independen memberikan hampir semua informasi yang dibutuhkan untuk memprediksi variabel dependen (Ghozali, 2011).

\section{Uji Hipotesis}

Pengujian hipotesis dalam penelitian ini menggunakan metode pengujian dengan regresi berganda, untuk memprediksi besar variabel dependen dengan menggunakan data variabel independen yang sudah diketahui besarnya (Ghozali, 2011). Persamaan regresi berganda dirumuskan sebagai berikut :

$$
\begin{aligned}
& \quad \mathrm{Y}=\alpha+\beta_{1} \mathrm{X}_{1}+\beta_{2} \mathrm{X}_{2}+\mathrm{e} \\
& \text { P. GUG }=\alpha+\beta_{1} \mathrm{SPI}+\beta_{2} \mathrm{PI}+\mathrm{e} \\
& \text { Keterangan : } \\
& \alpha \quad=\text { Konstanta } \\
& 108 \quad
\end{aligned}
$$


$\beta_{1} \& \beta_{2}=$ Koefisien Regresi

$\mathrm{Y} \quad=$ Pencapaian Good University Governance

$\mathrm{X}_{1} \quad=$ Satuan Pengawasan Intern

$\mathrm{X}_{2}=$ Pengendalian Internal

e $\quad=$ Error

\section{Uji Signifikansi Parameter Indvidual (uji t-statistik)}

Uji t bertujuan untuk menguji seberapa jauh pengaruh satu variabel independen secara individual yaitu satuan pengawasan intern dan Internal Control dalam menjelaskan variabel dependen yaitu pencapaian good university governance. Apabila tingkat signifikannya lebih kecil dari 0,05 maka Ha diterima. Demikian pula sebaliknya jika tingkat signifikan lebih besar dari 0,05 maka Ha ditolak. Bila Ha diterima dan Ho ditolak berarti ada hubungan signifikan antara variabel independen dengan variabel dependen (Ghozali, 2011).

\section{Uji Signifikan Simultan (Uji Statistik F)}

Uji statistik F dilakukan untuk mengetahui pengaruh semua variabel independen yang dimaksukkan ke dalam variabel model regresi secara bersama-sama terhadap variabel dependen (Ghozali, 2011). Kriteria yang dipakai untuk membuat keputusan terhadap hasil uji hipotesis yang diuji adalah berdasarkan tingkat signifikansi sebesar 0,05 yang merupakan probabilitas kesalahan sebesar 5\% dasar pengambilan keputusan adalah sebagai berikut :

Jika probabilitas $>0,05$ maka Ha Ditolak

Jika probabilitas $<0,05$ maka Ha Diterima

Tabel 2

Operasional Variabel Penelitian

\begin{tabular}{|c|c|c|c|}
\hline Variabel & \multicolumn{2}{|r|}{ Indikator } & $\begin{array}{l}\text { Butir } \\
\text { Soal }\end{array}$ \\
\hline \multirow{3}{*}{$\begin{array}{l}\text { Peran Satuan } \\
\text { Pengawasan } \\
\text { Internal } \\
\text { (Sawyer,dkk, } \\
\text { 2010) }\end{array}$} & Audit Snoop & $\begin{array}{l}\text { Ketaatan atau kepatuhan terhadap } \\
\text { ketentuan }\end{array}$ & $1-8$ \\
\hline & Consultant & Operasional audit/performance audit & $9-16$ \\
\hline & $\begin{array}{l}\text { Management's } \\
\text { representative }\end{array}$ & Quality assurance & $17-24$ \\
\hline \multirow{13}{*}{$\begin{array}{c}\text { Pengendalian } \\
\text { Internal } \\
(\text { COSO,2013: 70) }\end{array}$} & \multirow{3}{*}{$\begin{array}{l}\text { Lingkungan } \\
\text { Pengendalian }\end{array}$} & Integritas dan etika & $1-2$ \\
\hline & & Pemberian wewenang & 3 \\
\hline & & Struktur organisasi & 4 \\
\hline & \multirow{2}{*}{$\begin{array}{l}\text { Penetapan } \\
\text { resiko }\end{array}$} & Mengidentifikasi organisasi & 5 \\
\hline & & Pengelolaan resiko & 6 \\
\hline & \multirow{4}{*}{$\begin{array}{c}\text { Aktivitas } \\
\text { pengendalian }\end{array}$} & Efektivitas pengendalian internal & 7 \\
\hline & & Pemisahan tugas & 8 \\
\hline & & Petuh terhadap kebijakan & 9 \\
\hline & & Prinsip kepatuhan & 10 \\
\hline & \multirow{2}{*}{$\begin{array}{l}\text { Informasi dan } \\
\text { komunikasi }\end{array}$} & $\begin{array}{l}\text { Kelengkapan, akurat, tepat waktu } \\
\text { informasi }\end{array}$ & 11 \\
\hline & & Computer based & 12 \\
\hline & \multirow{2}{*}{ Pemantauan } & Penilaian pengendalian internal & 13 \\
\hline & & Tindakan monitoring & 14 \\
\hline Good University & Transparansi & Transparansi rencana & 1 \\
\hline
\end{tabular}


PERAN SATUAN PENGAWASAN INTERN DAN PENERAPAN PENGENDALIAN INTERNAL

Dri Asmawanti S dan Siti Aisyah

\begin{tabular}{|c|c|c|c|}
\hline \multirow{16}{*}{$\begin{array}{c}\text { Governance (GUG) } \\
\text { (Y) (Wijatno,2009: } \\
390)\end{array}$} & & Transparansi sistem & 2 \\
\hline & \multirow{3}{*}{ Akuntabilitas } & $\begin{array}{l}\text { Dokumentasi dan komunikasi pihak } \\
\text { intern dan ekstern }\end{array}$ & 3 \\
\hline & & $\begin{array}{l}\text { Tugas \& tanggung jawab perguruan } \\
\text { tinggi }\end{array}$ & 4 \\
\hline & & Efektivitas pengendalian internal & $5-6$ \\
\hline & \multirow{4}{*}{ Responsibilitas } & Prinsip kehati-hatian & 7 \\
\hline & & Prinsip kepatuhan & $8-9$ \\
\hline & & $\begin{array}{l}\text { Tanggungjawab terhadap lingkungan } \\
\text { \&masyarakat }\end{array}$ & 10 \\
\hline & & Kesinambungan jangka panjang & 11 \\
\hline & \multirow{4}{*}{ Independensi } & Bebas dari dominasi & 12 \\
\hline & & Bebas dari benturan intern \&ekstern & 13 \\
\hline & & Pengambilan keputusan & 14 \\
\hline & & Bebas dari sikap lempar tanggungjawab & 15 \\
\hline & \multirow{4}{*}{ Keadilan } & Keadilan terhadap semua kepentingan & 16 \\
\hline & & Kesempatan berpartisipasi & 17 \\
\hline & & Kebijakan kompensasi positif & 18 \\
\hline & & Kebijakan kompensasi negative & 19 \\
\hline
\end{tabular}

\section{HASIL DAN PEMBAHASAN}

Hasil pengujian hubungan antara peran satuan pengawasan intern dan penerapan pengendalian internal terhadap pencapaian Good University Governance menggunakan kuesioner yang disebarkan langsung kepada responden. Hipotesis pada penelitian ini diuji dengan menggunakan regresi berganda. Berikut ini data deskriptif untuk variabel yang digunakan dalam penelitian ini :

Tabel 3

Deskriptif statistik

\begin{tabular}{l|l|l|l|l|l}
\hline & $\mathrm{N}$ & Minimum & Maximum & Mean & Std. Deviation \\
\hline SPI & 33 & 59 & 97 & 81.79 & 9.516 \\
\hline PI & 33 & 39 & 60 & 48.85 & 6.310 \\
\hline GUG & 33 & 53 & 100 & 80.55 & 10.402 \\
\hline Valid N (listwise) & 33 & & & & \\
\hline
\end{tabular}

Tabel diatas menunjukkan bahwa rata-rata SPI adalah 81.79, pengendalian internal sebesar 48.85 dan Good University Governance sebesar 80.55. Nilai SPI sebesar 81.79 menunjukkan bahwa sebagian besar responden menjawab bahwa peran satuan pengawasan internal bersifat Netral. Variabel Pengendalian Internal sebesar 48.85, hal ini berarti sebagian besar responden menjawab Netral. Variabel Good University Governance sebesar 80.55 hal ini menunjukkan bahwa sebagian besar responden menjawab Setuju.

\section{Uji asumsi klasik}

Dalam penelitian ini, uji normalitas yang digunakan adalah uji Kolmogorov-Smirnov dengan melihat nilai Asymp. Sign (2-tailed) dengan probabilitas 0,05. Jika nilai Asymp. Sign (2-tailed) lebih besar dari 0,05 maka data residual terdistribusi normal. Sedangkan jika nilai Asymp. Sign (2-tailed) lebih kecil dari 0,05 maka data residual terdistribusi tidak normal. 
Hasil uji normalitas untuk SPI, PI dan dan GUG terdistribusi normal, karena memiliki nilai Asymp Sig > 0,05.

Tabel 4. Hasil Uji Normalitas

\begin{tabular}{l|c|c|c}
\hline Variabel & Kolmogorov-Smirnov & Asymp. Sig. (2-tailed) & Ket. \\
\hline SPI & 0,111 & 0,055 & Normal \\
\hline PI & 0,100 & 0,200 & Normal \\
\hline GUG & 0,111 & 0,065 & Normal \\
\hline \multicolumn{2}{l}{ Sumber : data sekunder diolah, 2017}
\end{tabular}

Untuk melihat ada atau tidaknya masalah multikolinieritas dapat dilihat dari nilai Tolerance dan Variance Inflation Factor (VIF). Jika nilai tolerance $>0,1$ dan nilai VIF $<10$ maka tidak terjadi masalah multikolinieritas dan model regresi dapat dikatakan baik. Sedangkan jika nilai tolerance $<0,1$ dan nilai VIF $>10$ maka terjadi masalah multikolinieritas dan model regresi dapat dikatakan tidak baik. Hasil uji multikolinieritas dengan variabel SPI, PI dan GUG memiliki masing-masing nilai tolerance sebesar 0,778>0,1 dan nilai VIF sebesar $1,139<10$ sehingga dapat disimpulkan tidak terjadi masalah multikolinieritas.

Tabel 5. Hasil Uji Multikolinieritas

\begin{tabular}{l|c|c|c}
\hline \multirow{2}{*}{ Variabel } & \multicolumn{2}{|c|}{ Collinearity Statistics } & \multirow{2}{*}{ Ket. } \\
\cline { 2 - 3 } & Tolerance & VIF & Bebas multikolinearitas \\
\hline GUG & 0,778 & 1.139 & Bebas multikolinearitas \\
\hline SPI & 0.938 & 1.066 & Bebas multikolinearitas \\
\hline PI & 0.931 & 1.074 & \\
\hline
\end{tabular}

Sumber : data sekunder diolah, 2017

Pengujian autokorelasi dilakukan dengan melihat nilai $d$ atau koefisien Durbin Watson (D-W). Hasil pengujian autokorelasi menggunakan uji Durbin-Watson (DW-Test) dengan jumlah variabel independen $(\mathrm{k})$ sebanyak 2 variabel, dengan jumlah observasi $(\mathrm{n})=$ 30 dan dengan $\alpha=5 \%$ dengan nilai Karena dU $<$ DW $<(4-\mathrm{dU})$. Adapun hasil uji autokorelasi dalam penelitian ini menghasilkan $1,739<1,872<2,261$, maka dapat disimpulkan tidak terdapat autokorelasi

Tabel 6. Hasil Uji Autokorelasi

\begin{tabular}{l|l|l|l|l|l}
\hline $\mathrm{n}$ & $\mathrm{k}$ & $\mathrm{Du}$ & $4-\mathrm{du}$ & $\mathrm{Dw}$ & Keterangan \\
\hline 30 & 3 & 1,739 & 2,261 & 1,872 & Tidak terdapat autokorelasi \\
\hline \multicolumn{6}{l}{ a. Predictors: (Constant), SPI, PI } \\
b. Dependent Variable: GUG
\end{tabular}

Untuk menentukan besarnya proporsi atau persentase total variansi dalam variabel terikat yang diterangkan oleh variabel bebas, peneliti menggunakan nilai R-Square. Adapun hasil yang diperoleh sebagai berikut : 


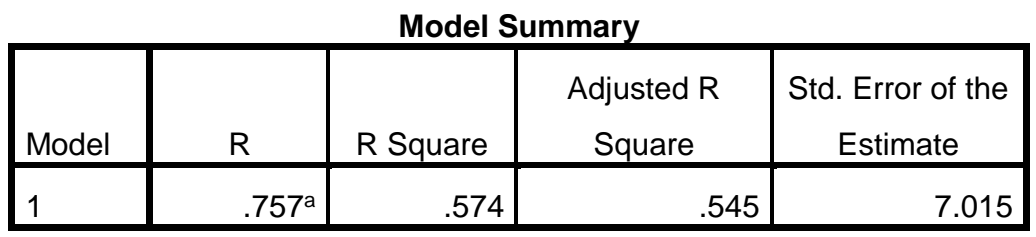

a. Predictors: (Constant), PI, SPI

Berdasarkan tabel diatas dan jumlah variabel bebas dalam penelitian ini adalah 2 (dua) buah, maka yang dilihat adalah Nilai R-Square. Angka menunjukkan nilai 0,574, hal ini berarti bahwa besarnya hubungan variabel SPI dan PI terhadap penerapan GUG sebesar $57,4 \%$, sedangkan sisanya $42,6 \%$ dipengaruhi oleh variabel lain diluar penelitian ini. Hasil uji F-Statistik akan memperlihatkan hasil pengaruh semua variabel independen yang dimasukkan ke dalam variabel model regresi secara bersama-sama terhadap variabel dependen (Ghozali, 2011). Kriterianya adalah Jika hasil tingkat signifikansi uji $\mathrm{F}$ menunjukkan nilai kurang dari (<) 0,05, maka penelitian ini dapat memberikan tambahan bukti bahwa terdapat hubungan yang signifikan antara variabel independen terhadap variabel dependen dalam penelitian ini. Berikut ini adalah hasil uji F-Statistik pada penelitian ini :

\begin{tabular}{|c|c|c|c|c|c|c|}
\hline \multicolumn{7}{|c|}{ ANOVA $^{a}$} \\
\hline & & Sum of Squares & df & Mean Square & $\mathrm{F}$ & Sig. \\
\hline \multirow[t]{3}{*}{1} & Regression & 1986.001 & 2 & 993.000 & 20.180 & $.000^{\mathrm{b}}$ \\
\hline & Residual & 1476.181 & 30 & 49.206 & & \\
\hline & Total & 3462.182 & 32 & & & \\
\hline
\end{tabular}

a. Dependent Variable: GUG

b. Predictors: (Constant), PI, SPI

Dari hasil tabel diatas, Nilai signifikansi yang diperoleh adalah sebesar 0,000 yang memiliki nilai kurang dari $(<)$ 0,05, maka dapat disimpulkan secara bersama-sama variabel peran satuan pengawasan intern dan penerapan pengendalian internal memiliki hubungan yang signifikan terhadap pencapaian Good University Governance.

\section{Hasil Uji Signifikansi Parameter Individual ( Uji Statistik t)}

Uji t-statistik dilakukan untuk melihat uji secara parsial yang dilakukan terhadap pengujian hipotesis penelitian. Jika Nilai t-hitung lebih besar (>) dari t-tabel, maka disimpulkan bahwa terdapat pengaruh yang signifikan antara variabel independen terhadap variabel dependennya pada setiap hipotesis penelitian. Berikut ini adalah hasilnya.

\begin{tabular}{|c|c|c|c|c|c|c|}
\hline \multicolumn{7}{|c|}{ Coefficients $^{a}$} \\
\hline \multirow{2}{*}{\multicolumn{2}{|c|}{ Model }} & \multicolumn{2}{|c|}{ Unstandardized Coefficients } & \multirow{2}{*}{$\begin{array}{c}\text { Standardized } \\
\text { Coefficients }\end{array}$} & \multirow[b]{2}{*}{$t$} & \multirow[b]{2}{*}{ Sig. } \\
\hline & & $\mathrm{B}$ & Std. Error & & & \\
\hline \multirow[t]{3}{*}{1} & (Constant) & -.232 & 14.837 & & -.016 & .988 \\
\hline & SPI & .268 & .131 & .245 & 2.050 & .049 \\
\hline & $\mathrm{PI}$ & 1.206 & .197 & .731 & 6.124 & .000 \\
\hline
\end{tabular}

a. Dependent Variable: GUG 
Berdasarkan tabel diatas, dapat dilihat nilai t-hitung untuk variabel SPI menunjukkan angka 2.050 dan variabel PI menunjukkan angka $6.124>$ t-tabel $(2,04227)$, dan nilai signifikansi pada kedua variabel adalah 0,049 dan 0,000<0,05, maka dapat disimpulkan bahwa terdapat bukti adanya hubungan positif yang signifikan antara peran Satuan Pengawasan Intern terhadap Penerapan Good University Governance. Variabel penerapan pengendalian Internal mendapatkan kesimpulan yang sama, yaitu terdapat bukti adanya hubungan yang signifikan antara Penerapan pengendalian Internal terhadap Pencapaian Good University Governance. Dilihat dari nilai Koefisien Beta untuk variabel SPI dan PI, semuanya memiliki angka yang positif (0.268 dan 1.206), hal ini menunjukkan bahwa hubungan variabel independen terhadap variabel dependen memiliki arah yang positif.

Dari hasil uji data diatas, maka dalam upaya pencapaian Good University Governance, peran Satuan Pengawasan Intern sangatlah penting karena bertugas meneliti dan mengevaluasi suatu sistem akuntansi serta menilai kebijakan manajemen yang dilaksanakan. Hal ini menunjukkan bahwa keberhasilan Peran Satuan Pengawasan Intern dalam sebuah perguruan tinggi mampu meningkatkan keberhasilan penerapan prinsip Good University Governance. Hal ini konsisten dengan peneliti sebelumnya Untari (2015) dan Puspitarini, dkk (2013) yang memperoleh hubungan yang positif dan signifikan pula. Sementara itu, Penerapan Pengendalian Internal dalam sebuah perguruan tinggi memiliki hubungan yang sangat erat dengan pengimplementasian dan pencapaian Good University Governance. Hal ini berarti bahwa pengendalian internal yang baik akan mendorong ketercapain tujuan strategis penerapan Good University Governance. Hasil penelitian ini konsisten juga dengan penelitian yang dilakukan Untari (2015). Penerapan komponen dari pengendalian internal yang baik diharapkan tata kelola perguruan tinggi yang baik akan tercapai pula.

\section{PENUTUP}

\section{Simpulan}

Pencapaian Good University Governance di Perguruan Tinggi Negeri Kota Bengkulu dapat dilihat dari peran satuan pengawasan internal dan penerapan pengendalian internal perguruan tinggi tersebut. Setiap institusi pendidikan yang memiliki SPI bertugas meneliti dan mengevaluasi suatu sistem akuntansi dan kebijakan manajemen memiliki hubungan yang positif dengan tercapainya penerapan Good University Governance secara efektif dan efisien. Perguruan tinggi mampu memberikan kontribusi yang positif melalui pengimplementasian prinsip Good University Governance yang dibantu oleh satuan kerjanya, yaitu Satuan Pengawasan Intern dan Pengendalian Internal. Sistem pengendalian yang efektif dapat menjamin operasional perguruan tinggi yang efektif dan efisien pula serta dipatuhiya aturanaturan internal dan eksternal institusi yang pada akhirnya dapat terwujudnya akuntabilitas yang baik dalam perguruan tinggi tersebut. 


\section{DAFTAR PUSTAKA}

Cooper, Donald R,\& Schinder, Pamela S. 2012. Business Research Methods, $12^{\text {th }}$ edition. New York : McGraw-Hill.

Coso. 2012. Internal Control - Integrated Framework. Post Public Exposure Version.

Ghozali, Imam. 2011. Structural Equation Modelling Metode Alternatif dengan Pertial Least Square.Edisi 3. Semarang :Badan Penerbit Universitas Diponegoro.

Gusnardi. 2008. Internal Controls In Ensuring Good Corporate Governance In Financial Intitution. peneliti Dikti. Pekanbaru.

Peraturan Menteri Pendidikan Nasional Republik Indonesia Nomor 47 Tahun 2011, Tentang Satuan Pengawasan Intern Di Lingkungan Kementerian Pendidikan Nasional. Jakarta : Biro Hukum Dan Organisasi Kementerian Pendidikan Nasional

Puspitarini, Noviana Dyah, Sukirman, dan Indah Anisykurlillah. 2013. Peran Satuan Pengawasan Internal (SPI) Dalam Pencapaian Good University Governance (GUG) Pada Perguruan Tinggi Se-Jawa Yang Berstatus Pola Pengelolaan Keuangan Badan Layanan Umum (PK-BLU). Symposium Seminar Akuntansi (SNA). Manado.

Raharjo, Eko. 2007. Teori Agensi dan Teori Stewarship dalam perspektif akuntansi. Fokus Ekonomi, vol.2 No.1 Juni 2007: 37-46.ISSN: 1907-6304

Sawyer, Lawrence B., Mortimer A Dittenhofer, James H Scheinder. 2010. Intern Auditing. Jakarta: Salemba Empat

Tugiman, Hiro.1997. Standar Profesional Audit Internal. Yogyakarta: Kanisius.

Untari. 2015. Pengaruh Peran Satuan Pengawasan Intern (SPI) dan Penerapan Internal Control Terhadap Pencapaian Good University Governance (GUG).Jakarta.

Wijatno, Serian. 2009. Pengelolaan Perguruan Tinggi secara efisien, efektif dan Ekonomis untuk Meningkatkan Penyelenggaraan Pendidikan dan Mutu Lulusan. Jakarta : Salemba Empat.

Zarkasyi. Moh. Wahyudin. 2008. Good Corporate Governance Pada Badab Usaha Manufaktur, Perbankan Dan Jasa Keuangan Lainnya. Bandung: Alfabet. 